\title{
Correlation between Physical and Engineering properties of Tropical peat soils from Sarawak
}

Conference Paper in Geotechnical Special Publication · December 2010

DOI: $10.1061 / 41101(374) 9$

CITATIONS

5

4 authors:

Prabir K. Kolay

Southern Illinois University Carbondale

98 PUBLICATIONS 735 CITATIONS

SEE PROFILE

M.A Rahman

Deakin University

15 PUBLICATIONS 321 CITATIONS

SEE PROFILE
READS

424

Aminur Aminur

halu oleo university

7 PUBLICATIONS 45 CITATIONS

SEE PROFILE

Siti Noor Linda Taib

University Malaysia Sarawak

32 PUBLICATIONS 123 CITATIONS

SEE PROFILE

Some of the authors of this publication are also working on these related projects:

Environmental Geotechnics View project 


\title{
Correlation Between Different Physical and Engineering Properties of Tropical Peat Soils from Sarawak
}

\author{
P.K. Kolay ${ }^{1}$, M.R. Aminur ${ }^{2}$, S.N.L. Taib ${ }^{3}$, M.I.S. Mohd Zain ${ }^{4}$ \\ ${ }^{1}$ Assoc. Professor, ${ }^{2}$ Master Student, ${ }^{3}$ Senior Lecturer, ${ }^{4}$ Assoc. Professor, Department of Civil Engg, \\ University Malaysia Sarawak, 94300 Kota Samarahan, Sarawak, Malaysia; kkprabir@feng.unimas.my
}

\begin{abstract}
The present paper describes the physical and engineering properties of tropical peat soils from Sarawak, Malaysia. Different physical properties such as organic content (OC), liquid limit (LL), fibre content (FC), specific gravity $\left(\mathrm{G}_{\mathrm{s}}\right)$ and engineering properties (mainly the standard Proctor test) have been conducted on remoulded peat soil samples. The results show that, the value of LL, FC, Optimum Moisture Content (OMC) increases with an increase in OC. Also the results show that, $\mathrm{G}_{\mathrm{s}}$ and MDD decrease with increasing values of OC. Furthermore, the plot of OC against $\mathrm{G}_{\mathrm{s}}$ from the current study is compared with other researchers; whereby the correlation shows that $\mathrm{R}^{2}$ values ranges from 0.71 to 0.95 . This demonstrates that findings on local peat soils from Sarawak are in good agreement with other researchers as similar trends are observed. Consequently, geotechnical engineers can refer these correlations to comprehend the preliminary behavior of peat soil, where the geotechnical data are not readily available.
\end{abstract}

\section{INTRODUCTION}

Peat or highly organic soils are extreme soft and non-homogeneous. These soils are partly decomposed and fragmented remains of plants leaves, roots that have accumulated under water and fossilized. Normally the peat soils are formed in wetland bogs, moors, muskegs, mires, and peat swamp forests and they cover 5 to $8 \%$ of the total land area of the Earths surfaces. Among them about 8 to $11 \%$ are tropical peat soils which includes Indonesia, Malaysia, Brazil, Uganda, Zambia, Zambia, Venezuela, and Zaire (Mesri \& Ajlouni, 2007). Malaysia covers approximately 2.7 million hectares of peat lands and out of that about 1.66 million hectares (i.e. $61 \%$ ) are located in the deltas and coastal plains of Sarawak. Peat soils of Sarawak occupy 13\% of the total land area and most of the year; these areas are waterlogged (Mutalib et al., 1991). Due to the high water level in this area, it is very difficult to determine the physical and geotechnical properties of peat soil. Edil (1994) emphasizes on characterizing peat and organic soils by certain index properties, to provide a basis for comparison of results of mechanical tests. Hobbs (1986) also suggested that it is 